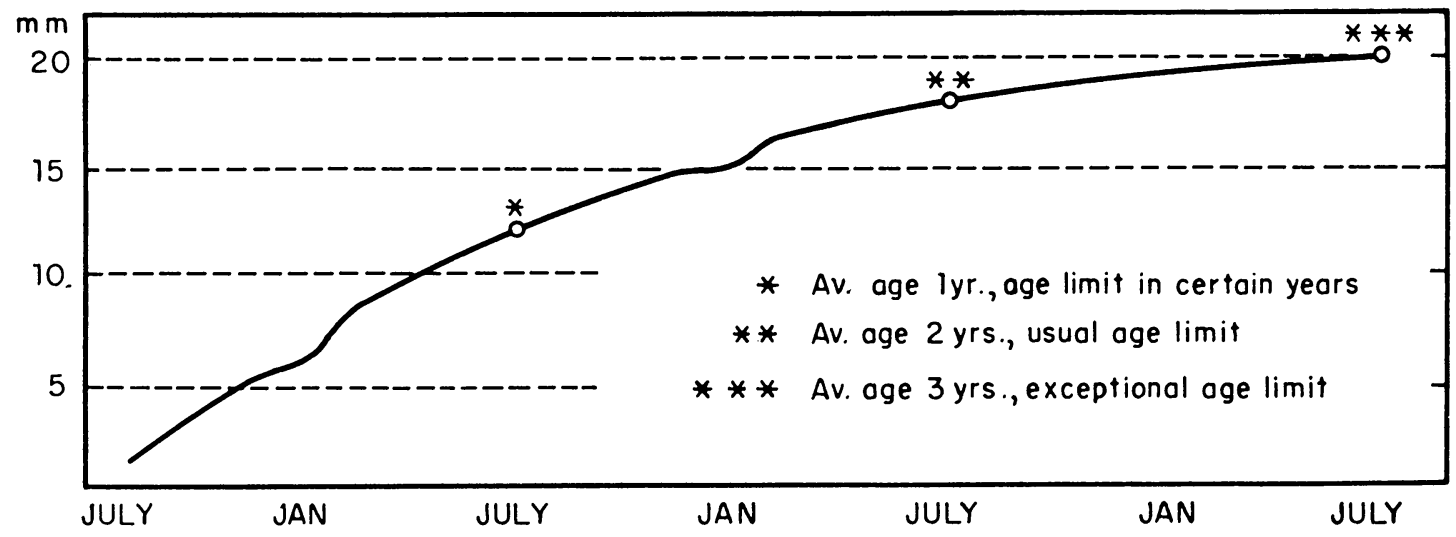

FI(i. 2. Average rates of growth of Donax gouldi at La Jolla. Individuals which set on the beach in early July reached an average length of $12 \mathrm{~mm}$. when one year of age and $18 \mathrm{~mm}$. at the age of two years. The relatively few survivors were about $20 \mathrm{~mm}$. long when they all died near the end of their third year.

The survivors average about $20 \mathrm{~mm}$. in length at the extreme age of three years. Shells more than $24 \mathrm{~mm}$. long are seldom found in this locality and in certain years the maximum size of spawning individuals is only $12-16 \mathrm{~mm}$.

Enemics. Gulls devour vast numbers of Donax of all sizes and regurgitate the empty shells. The clams are eaten also by rays and by several species of fishes, notably corvina and the surf perches. These fishes frequently bite off and devour the siphons of the clams instead of taking their whole bodies.

Parasites. Many of the clams, and in some areas most of them, are infested with trematodes, particularly Postmonorchis donacis Young (1953). The parasites are first found in the visceral mass of the body and when present in large numbers encroach upon the gonads to such an extent as to render the clam more or less completely sterile but without apparent loss of vigor. The parasites evidently absorb the nutrition which would otherwise be available for the development of the gametes. The young parasites enter the connective tissue of the visceral mass and become sporocysts. These increase in size and produce the tailed cercariae. The latter give rise to the metacercariae which later encyst at the base of the siphons and edges of the mantle, as well as in the gills. The adults presumably live in the rectum of fishes (Young 1953).

A far more injurious parasite is the minute unicellular organism which sometimes contributes to the death of the entire local population, as mentioned in a preceding paragraph.

\section{SUMMARY}

This paper summarizes the results of observations during seventeen years on the habits and habitat, food, rates of growth at different ages and seasons, periods and conditions of spawning, enemies, and parasites. Data relative to the seven resurgent populations which have appeared on that beach in the past sixty years are included. In the resurgence of 1949 the population changed from an average of less than one clam per square meter to more than 20,000 within two months. An epidemic disease soon developed and the mortality became so great that within three years less than a dozen individuals, old or young, could be found in an area formerly occupied by millions. A minute unicellular organism was apparently responsible.

\section{REFERENCES}

Coe, W. R. 1948. Nutrition, environmental conditions, and growth of marine bivalve mollusks. J. Mar. Res., 7 : 586-601.

Coe, W. R. 1953. Resurgent populations of littoral marine invertebrates and their dependence on ocean currents and tidal currents. Ecology, 34: 225-229.

Fitch, J. E. 1953. Common marine bivalves of California. Calif. Dept. Fish and Game, Fish. Bull. No. $90: 1-102$.

Mackin, J. G. 1951. Histopathology of infection of Crassostrea virginica (Gmelin) by Dermocystidium marinum Mackin, Owen, and Collier. Bull. Mar. Sci. Gulf and Carib., 1: 72-87.

Pelseneer, P. 1928. Les parasites des mollusques et les mollusques parasites. Bull. Soc. Zool. France, 53: 158-189.

Young, R. T. 1953 . Postmonorchis donacis, a new species of monorchid trematode from the Pacific coast, and its life history. J. Washington Acad. Sci., 43 : 88-93.

\section{Wesley R. Coe}

SCRIPPS INSTITUTION OF OCEANOGRAPHy, La Jolla, California

\title{
VEGETATION AND THE ALIGNMENT OF ENVIRONMENTAL FORCES
}

Yet another general interpretation of climax vegetation in terms of the alignment of environmental forces has recently been proposed in a preliminary note to Ecology (Dansereau 1954). The processes of vegetation development are envisaged as dependent upon a relay of factors, with successive release from edaphic to biotic and finally to climatic control, and with all seres theoretically convergent upon the climax.

To the present writer, such an interpretation seems unlikely to be of general validity. Inasmuch as spatial variation or temporal change in soil, biota, topography, or climate may effect differences or changes at any stage 
of succession, the complexity of pattern and process in both vegetation and soil is clearly a reflection of the continual interaction of several partially independent ecosystem factors (Jenny 1941, Major 1951, Crocker 1952, Billings 1952).

Edaphic differences--such as those between limestone drift, non-calcareous clay, and sterile sand-will certainly have a selective effect on pioneer plants, but will also be of extremely great importance for their successors. Moreover, there is little reason to believe that differences in soil parent material can always be overcome to the extent that they cease to influence plant distribution (Beadle 1951). Nor can rhythms and extremes of climatic factors -moisture, temperature and light--ever fail to affect vegetation at all stages of its development, including the germination and establishment of the very first colonizing disseminules. Topography may likewise condition entire plant successions - through its effects on drainage, leaching, aggrading and degrading surfaces, microclimate and biotic isolation. Lastly, the availability of disseminules, and their tolerances, will directly determine pioneer floras no less than succeeding ones. Differences in powers of dispersal must have been of extreme importance just after the retreat of the great ice sheets, and are still of fundamental significance for vegetation patterns today (Harrison 1951). To such an extent, the biotic factor is involved in the very earliest stages of vegetation formation, although it is of course a truism that in the course of succession, organisms become ever more important in determining the nature of the environment itself.

Since all the above factors are operative everywhere and at all times, we may conclude that regional and temporal alignments of environmental controls are of necessity inter-related, and depend upon how effectively each ecosystem factor varies in both space and time. In this connection, the possibility of factor compensation must always be borne in mind (Billings 1952). Single factors may undoubtedly control plant distribution over limited areas, within which variation of other factors is insufficient to influence any of the floristic elements. However, the multi-factorial hypothesis referred to above would appear to allow a clearer interpretation of such cases than the rather artificial concept of a theoretical climatic climax, inhibited in certain circumstances by topographic, edaphic, or biotic factors.

The above arguments can best be considered with reference to particular cases, and most ecologists will no doubt wish to test their validity for areas with which they are familiar. Here it may suffice to examine briefly the situation in northern Britain-so ably described by Pearsall (1950) - in relation to Dansereau's views.

According to Dansereau, soil parent material exerts a strong selection upon pioneer plants, which must endure physico-chemical adversity. Hence, high tolerance and low requirements prevail in early stages of succession, under cdaphic dominance. In contrast, the climax is said to exhibit high requirements and low tolerance, with effici- ent utilization of a rich environment under climatic control. However, in northern Britain, postglacial soil development has probably involved floristic restriction, through depletion of plant nutrients and drainage impedance. In both wet and dry sites, it is unlikely that the original glacial drift, rich in easily soluble plant nutrients, exerted more physico-chemical selection upon the picneer flora than upon present vegetation, though it must have been different in kind. Soil texture was of course very different, and available nitrogen may have been scarce, although a good deal may be supplied from the atmosphere. However, the vegetation of today is strongly conditioned by edaphic factors, in that leaching and drainage impedance must have gradually ousted more demanding species from large areas colonized in early postglacial times. Nany such plants are now confined to flushed or unstable soils (Godwin 1949). 'Thus, it can scarcely be maintained that the climax vegetation in northern Britain exploits a rich environment as regards nutrients, though it may tolerate (or require) high moisture. It may even be doubted whether the standing crop of vegetation has increased since the establishment of a closed cover. The hypothesis of ultimate climatic dominance also fails in this region, for Pearsall (1950) has abundantly demonstrated that variations in each ecosystem factor are of very great importance in determining vegetation pattern and development.

\section{REFFRENCES}

Beadle, N. C. 1951. The misuse of climate as an indicator of vegetation and soils. Ecology 32: 343345.

Billings, W. D. 1952. The environmental complex in relation to plant growth and distribution. Quart. Rev. Biol. 27 : 251-265.

Crocker, R. L. 1952. Soil genesis and the pedogenic factors. Quart. Rev. Biol. 27 : 139-168.

Dansereau, P. 1954. Climax vegetation and the regional shift of controls. Ecology 35: 575-579.

Godwin, H. 1949. The spreading of the British flora considered in relation to conditions of the late-glacial period. Jour. Ecology 37 : 140-147.

Harrison, J. H. 1951. Fresh aspects of Irish vegetational problems: I and II. Irish Naturalists Jour. 10 : $125-130$ and $145-149$.

Jenny, H. 1941. Factors of soil formation. McGrawHill Book Co., New York and London.

Major, J. 1951. A functional, factorial approach to plant ecology. Ecology 32: 392-412.

Pearsall, w. H. 1950. Mountains and moorlands. Collins, London.

Evitle Gorham

Freshumater Brological. Association,

The Ferry House, far Sainey,

A M BLESIDE, WESTMORI.ANI,

ENGLAND 